
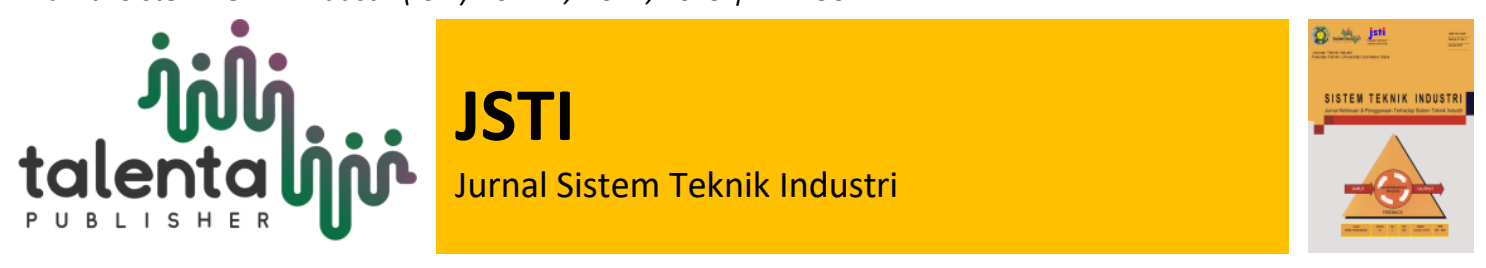

\title{
Optimisasi Proses Manufaktur Menggunakan DFMA Pada Pt. Xyz
}

\author{
Rosnani Ginting1, M. Ghassan Fattah ${ }^{2}$ \\ ${ }^{1,2}$ Departmen of Industrial Engineering Fakultas Teknik, Universitas Sumatera Utara
}

\begin{abstract}
Abstrak. Optimisasi adalah sebuah metode yang dinamis karena terus berubah untuk prosesproses yang berbeda maka sebuah pendekatan aplikatif diperlukan untuk mendapatkan pengertian yang lebih baik tentang optimisasi. PT. XYZ adalah sebuah perusahaan yang berbasis di Medan-Indonesia yang memproduksi produk-produk sanitary ware, produk yang paling banyak di produksi adalah kloset jongkok tipe $\mathrm{E}$ yang akan dibahas dalam jurnal ini. DFMA digunakan dengan mempertimbangkan masukan dari QFD level 2 yang didapat dari studi literatur lalu proses perancangan ulang dilakukan perancangan ulang produk, material selection, dan perbaikan peta kerja operation process chart. Hasil yang didapat dari desain porudk baru adalah pengurangan kebuhutuhan material sebanyak $78 \%$ dan pengurangan operasi sebanyak $22 \%$.
\end{abstract}

Kata kunci: Optimisasi, QFD, DFMA, Material Selection, Operation Process Chart.

\begin{abstract}
Abstrack. Optimization is a dynamic method because it keeps changing for different processes so an applicative approach is needed to get a better understanding of optimization. PT. XYZ is a Medan-Indonesia based company that manufactures sanitary ware products, the most produced product is the type E squat toilet which will be discussed in this journal. DFMA is used by considering the input from level 2 QFD obtained from the literature study, then the redesign process is done by product redesign, material selection, and improvement of the operation process chart work map. The results obtained from the new porcelain design are a reduction in material needs of $78 \%$ and a reduction in operations by $22 \%$.
\end{abstract}

Keywords: Optimization, QFD, DFMA, Material Selection, Operation Process Chart

Received 11 January 2019 | Revised 26 January 2019| Accepted 26 January 2019

\section{Pendahuluan}

Perancangan dan merancang merupakan suatu usaha untuk menyusun, mendapatkan, dan menciptakan hal-hal baru yang bermanfaat bagi kehidupan manusia [1]. Salah satu kekurangan dari perancangan produk adalah terlalu fokus pada keinginan konsumen sehingga tidak mengindahkan proses manufaktur produk itu sendiri yang dapat mengakibatkan keterlambatan pemenuhan pesanan produk dikarenakan masalah pada proses manufaktur.

Studi kasus dilakukan di PT. XYZ, sebuah perusahaan yang memproduksi sanitary ware yang terletak di Medan, Sumatera Utara. Perusahaan ini memproduksi beberapa jenis produk sehingga

*Corresponding author at: Jl Almamater, Medan 20155

E-mail address: gsiregarm@gmail.com 
dipilih produk dengan volume produksi tertinggi yaitu Kloset Jongkok Tipe E. Dari hasil observasi disusunlah sebuah Quality Function Deployment (QFD) untuk mengindentifikasi proses manufaktur mana yang memiliki pengaruh terbesar kepada keseluruhan proses manufaktur. QFD adalah sebuah proses yang menyediakan strukturpengembangan siklus produk. Struktur ini dapat dihubungkan pada sebuah kerangka berbentuk rumah [2]. QFD level 2 digunakan karena dapat menunjukan perakitan, sistem, sub-sistem, dan komponen yang memiliki pengaruh terbesar dalam proses. Hasil pengolahan data menunjukan bahwa proses pengeringan dan scrapping adalah proses yang paling memiliki pengaruh pada proses manufaktur [3].

Proses perancangan ulang produk dilakukan dengan metode Design for Manufature and Assembly (DFMA). DFMA DFMA merupakan hasil dari beberapa penelitian di University of Massachusetts (UMass) untuk mengembangkan metode analitik untuk menuntung perancang produk dalam pekerjaannya [2]. Dikarenakan proses manufaktur toilet jongkok lebih memberatkan proses manufaktur daripada perakitan, maka prinsip-prinsip yang digunakan adalah prinsip-prinsip Design for Manufacture (DFM) yang diantaranya: (i) Mengurangi jumlah komponen, (ii) Mengembangkan rancangan modular, (iii) Menggunakan komponen standar/serupa (iv) Mendesain part yang multiguna, dan (v) Mendesain untuk kemudahan manufaktur . Metode DFMA meliputi juga didalamnya material selection dan perbaikan petas operasi. [4]

Material Selection adalah suatu metode untuk mendapatkan bahan baku terbaik yang akan menyusun produk. Beberapa kriteria yang digunakan apabila suatu material dikatakan layak adalah reliabilitas, harga, dan ketersediaannya dipasar. [5] atau juga kebutuhan fungsional, kebutuhan pemrosesan, harga, reabilitas, dan ketahanan dalammemberikan layanan [4] tahapan material selection yang digunakan bertujuan untuk mendapatkan material yang lebih optimum dari material yang telah tersedia sehingga akan digunakan Metode Pugh. Metode Pugh mengembangkan suatu matriks dengan lambang (+) untuk kondisi material baru lebih baik, (-) untuk kondisi material baru lebih buruk, dan (0) untuk kondisi material baru dan material lama sama saja [4]. Berikut adalah contoh matriks dari metode Pugh.

Table 1 Matriks Metode Pugh

\begin{tabular}{lllll}
\hline Property & $\begin{array}{l}\text { Currently } \\
\text { Used Material }\end{array}$ & $\begin{array}{l}\text { New Material } \\
(\mathbf{1})\end{array}$ & $\begin{array}{l}\text { New Material } \\
(\mathbf{2})\end{array}$ & $\begin{array}{l}\text { New Material } \\
(\mathbf{3})\end{array}$ \\
\hline Property 1 & C1 & - & + & + \\
Property 2 & C2 & + & + & + \\
Property 3 & C3 & + & + & - \\
Property 4 & C4 & $\mathbf{0}$ & + & - \\
Property 5 & C5 & - & $\mathbf{0}$ & - \\
Property 6 & C6 & $\mathbf{0}$ & $\mathbf{0}$ & $\mathbf{0}$ \\
Property 7 & C7 & - & - & $\mathbf{0}$ \\
Property 8 & C8 & - & + & $\mathbf{0}$ \\
Property 9 & C9 & - & $\mathbf{0}$ & $\mathbf{0}$ \\
Total (+) & & $\mathbf{2}$ & $\mathbf{5}$ & $\mathbf{3}$ \\
Total (-) & & $\mathbf{5}$ & $\mathbf{1}$ & $\mathbf{4}$ \\
Total (0) & & $\mathbf{2}$ & $\mathbf{3}$ & Sumber : Mahmoud M Farag, Quantitative Method of Material Selection. John Wiley and Sons. HIm 19
\end{tabular}


Dalam jurnal ini selain menggunakan metode Pugh yang merupakan metode kuantitatif digunakan pula pendekatan yang lebih kreatif untuk mendapatkan material baru yang lebih optimum. Lalu terakhir dilakukan perbaikan peta operasi dengan menggunakan 4 prinsip untuk mengembangkan solusi yang mungkin atau metode yang lebih layak, prinsip-prinsip tersebut adalah a) Menghilangkan semua pekerjaan yang tidak penting, b) Menggabungkan operasi atau elemen, c) Mengganti urutan operasi, d) Menyederhakan operasi yang penting kita mencari prinsip-prinsip mana yang mungkin digunakan untuk melakukan perbaikan peta operasi lalu kita akan membandingkan hasil perbaikan tersebut dengan peta operasi awal.

Blok diagram dalam penelitian ini dapat dilihat pada gambar dibawah.

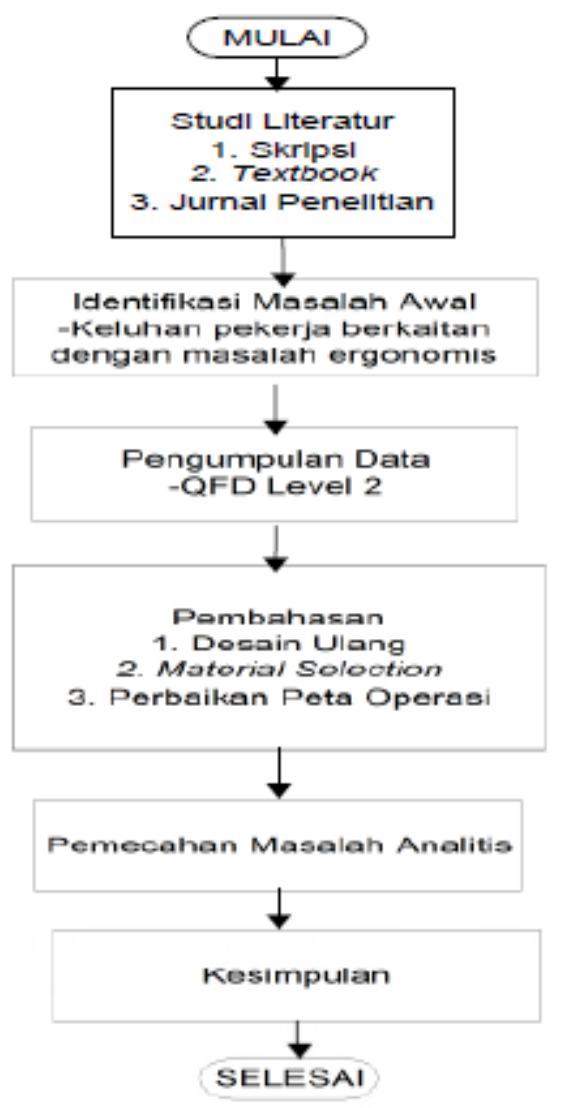

Figure 1 Research Block Diagram

Dari blok diagram diatas, penelitian dimulai dengan studi literatur dari skripsi untuk mendapatkan data observasi lapangan dari perusahaan dan analisis mengenai masalah yang ada pada proses manufaktur pada saat itu

Identifikasi masalah awal juga diambil dari data yang terdapat pada skripsi, meskipun tidak ada hubungan langsung antara masalah awal yang merupakan masalah ergonomic dengan proses manufaktur, tetapi hal ini dapat menjadi titik awal yang merupakan untuk optimasi keseluruhan proses yang lebih nyaman bagi pekerja. 
Pengumpulan didapat dari QFD level 2 yang menjelaskan tingkat kepetingan dari tiap proses pada proses manufaktur. Lalu pada pembahasan dilakukan dengan perancangan ulang pada produk dengan prinsip-prinsip DFMA, dilakukan pemilihan material yang lebih optimum dengan material selection, dan dilakukan optimasi keseluruhan proses operasi dengan perbaikan peta operasi

\section{Pembahasan}

Perancangan ulang dilakukan dengan mengacu pada prinsip-prinsip DFMA dan turunannya. Prinsip-prinsip yang digunakan antara lain:

a) Mendesain untuk kemudahan manufaktur

b) Mencegah pemrosesan khusus dan pergantian alat terus-menerus

c) Menspesifikasi penyelesaian permukaan yang lebih mudah

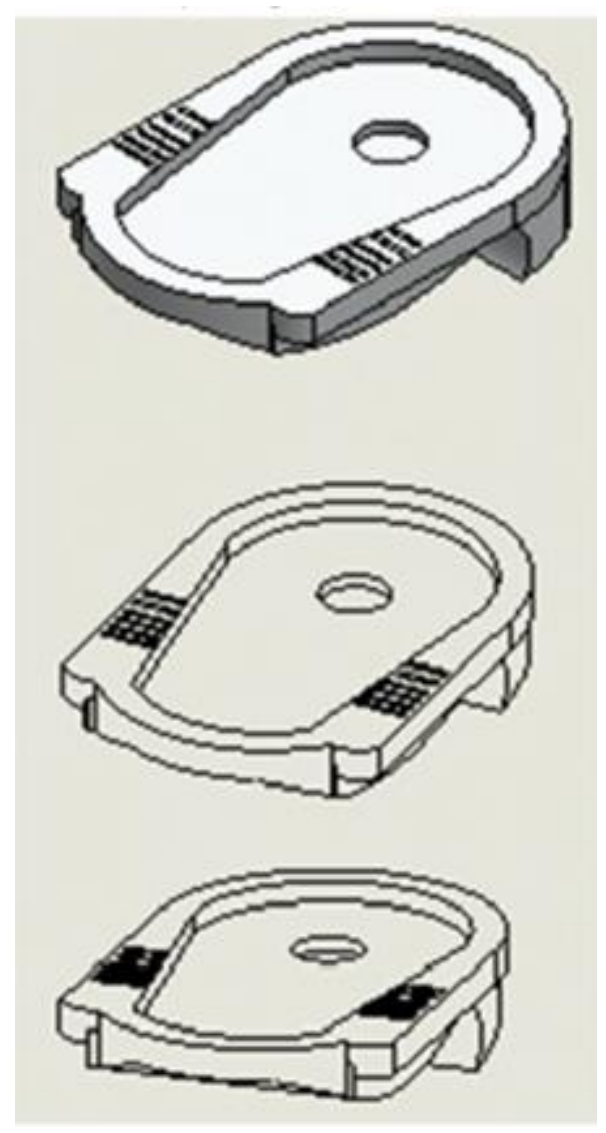

Figure 2 Desain Awal 


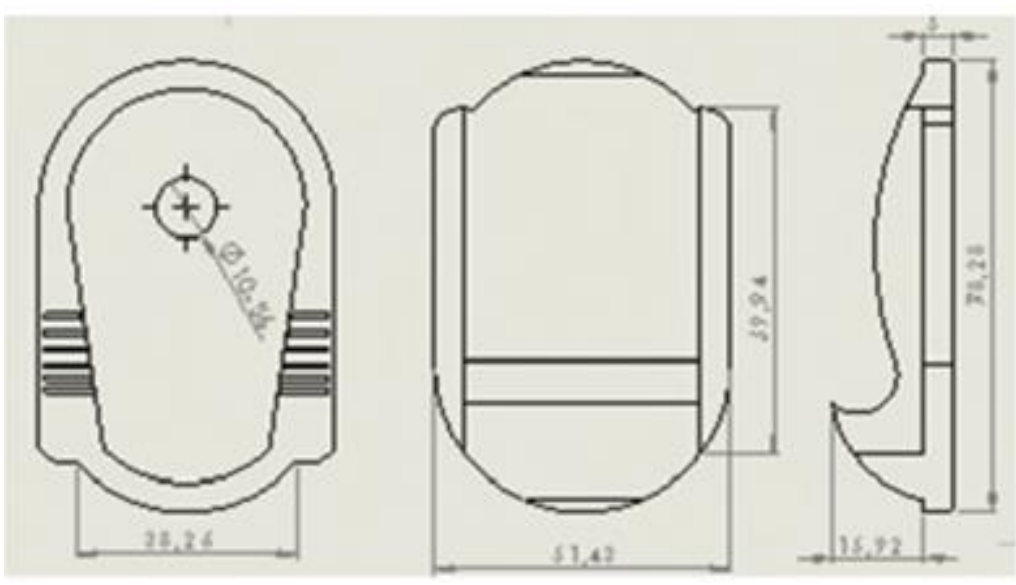

Figure 3 Spesifikasi Desain Awal

Rancangan pengembangan dapat dilihat pada gambar dibawah

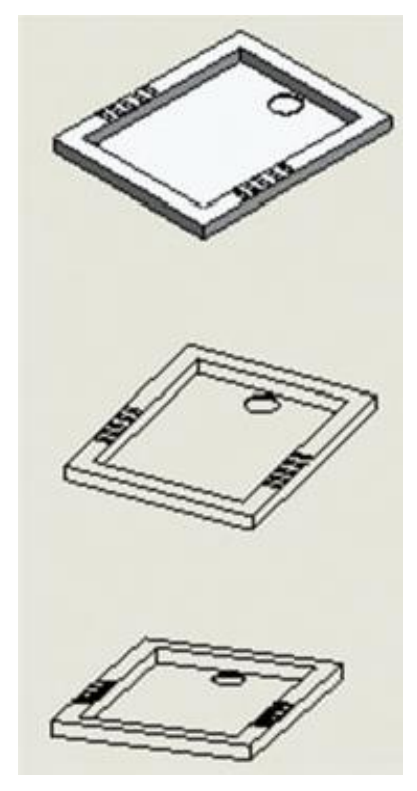

Figure 4 Desain Pengembangan
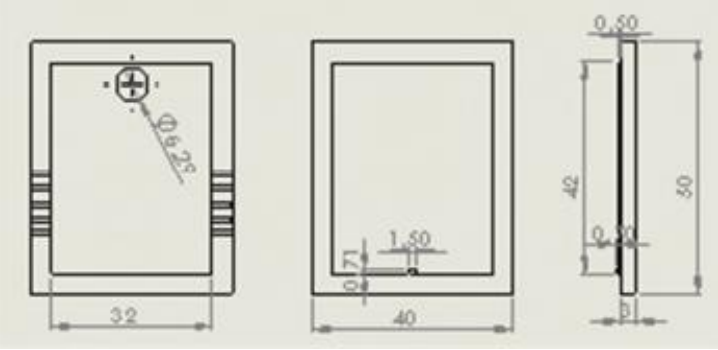

Figure 5 Spesifikasi Desain Pengembangan

Desain baru mengurangi penggunaan material dari $32311 \mathrm{~cm}^{3}$ menjadi dikarenakan pengurangan pada ukuran produk. Pengurangan ini juga memudahkan proses pencetakan. 


\section{A. Material Selection}

Material Selection digunakan untuk menganalisis material yang dapat mengurangi operasi dan biaya dengan metode Pugh maka dibandingkan penggunaan cat dari pigmen warna dalam tabel berikut

Table 2 Matriks Metode Pugh

\begin{tabular}{ccc}
\hline Properti & Cat & $\begin{array}{c}\text { Pigmen } \\
\text { Warna }\end{array}$ \\
\hline Biaya & C1 & $(+)$ \\
Pemrosesan & C2 & $(+)$ \\
Reablitas & C3 & $(0)$ \\
Total (+) & & 2 \\
Total (-) & & 0 \\
Total (0) & & 1 \\
\hline
\end{tabular}

Dari tabel matrik metode Pugh diatas disimpulkan bahwa penggunaan pigmen warna pada produk akan lebih baik karena memiliki unsur biaya yang lebih murah dan pemrosesan yang lebih mudah.Penggunaan pigmen warna juga menghilangkan proses pengecatan dari urutan proses manufaktur yang seharusnya dilakukan.

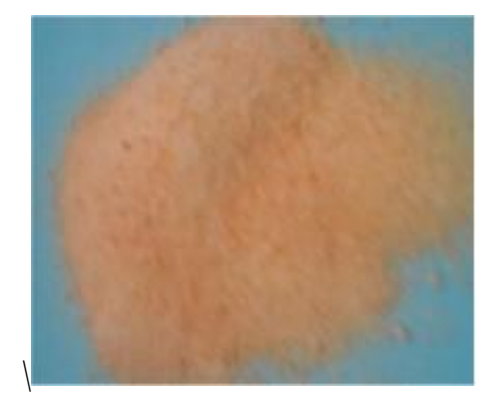

Figure 6 Pigmen Warna

Dilakukan juga penggantian material pengepakan dari sebelumnya menggunakan kayu dan paku menjadi menggunakan kardus agar menambah efisiensi waktu proses dan biaya.

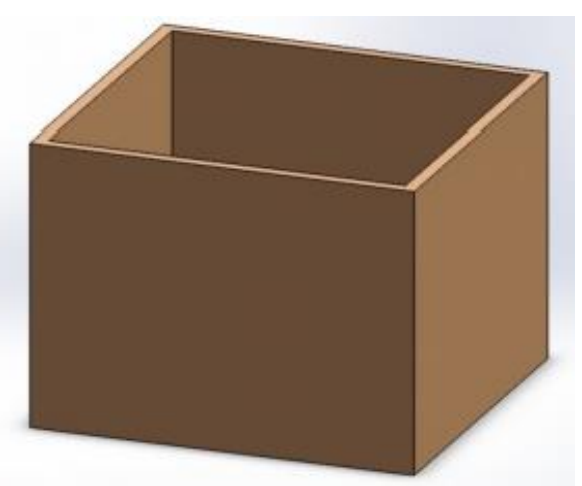

Figure 7 Kardus 


\section{B. Perbaikan Peta Operasi}

Peta operasi yang digunakan untuk menggambarkan proses manufaktur adalah operation process chart. Perbaikan peta operasi dilakukan dengan mempertimbangkan desain pengembangan dan material baru yang digunakan manufaktur produk, terdapat dua perbaikan yang dilakukan antara lain:

1) Eliminasi proses pewarnaan dikarenakan penambangan pigmen warna pada proses awal pencampuran bahan baku

2) Penggabungan proses scrapping dan pengamplasan yang akan dilakukan dalam satu stasiun

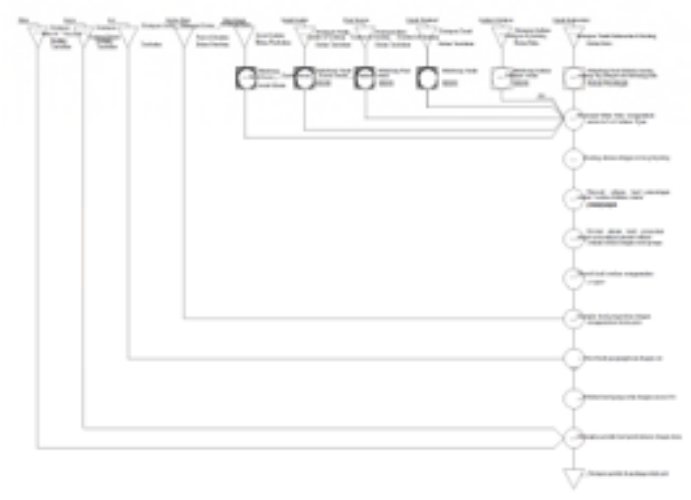

Figure 8 Operation Process Chart Awal

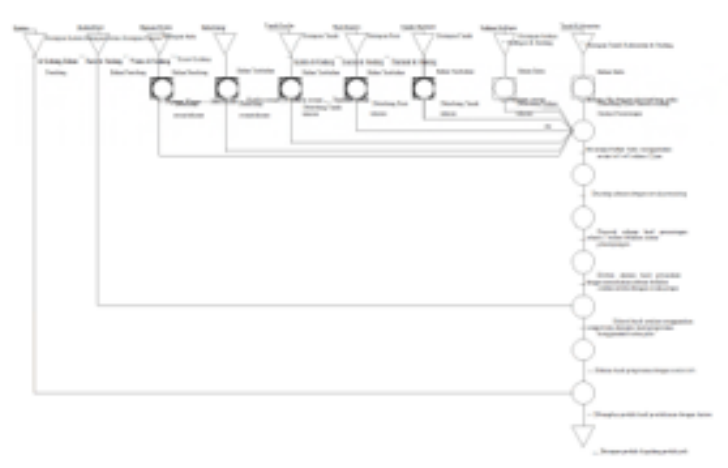

Figure 9 Operation Process Chart Perbaikan

Membandingkan kedua peta diatas maka didapat bahwa operation process chart pengembangan memiliki jumlah operasi yang lebih sedikit yakni 7 operasi dari sebelumnya 9 operasi pada operation process chart awal.

Spesifikasi awal dan pengembangan dapat dilihat pada tabel dibawah 
Table 3 Perbandingan Spesifikasi Awal

\begin{tabular}{ccc}
\hline Spesifikasi & Awal & Pengembangan \\
& & \\
\hline Material & $32311 \mathrm{~cm}^{3}$ & $6840 \mathrm{~cm}^{3}$ \\
Operasi & 9 & 7 \\
\hline
\end{tabular}

Dari tabel diatas kita menyimpulkan bahaw terjadi pengurangan material sebanyak $78 \%$ dan pengurangan operasi sebanyak $22 \%$

\section{Kesimpulan}

Terdapat dua kesimpulan yang didapat dari penelitian ini :

1) DFMA dapat digunakan untuk melakukan perancangan ulang produk untuk memudahkan proses manufaktur

2) Pengembangan yang didapat yakni pada penurunan penggunaan material sebanyak $78 \%$ dan jumlah operasi sebanyak $22 \%$

Penelitian lanjutan pada topik ini dapat dilakukan dengan menyelidiki pemilihan komponenkomponen tanah dasar sebagai penyusun keramik

\section{Ucapan Terima Kasih}

Tim Peneliti mengucapkan terimakasih banyak kepada alumni Teknik Industri, Universitas Sumatera Utara, Nixon Tandy karena telah menyediakan data obsevasi lapangan dan QFD yang diambil dari skripsi beliau 


\section{REFERENSI}

[1] A. P. Irawan, Perancangan dan Penngembangan Produk Manufaktur, Yogyakarta: ANDI, 2017.

[2] B. James L, Quality Function Deployment : a practicioner's approach, New York: ASQC Quality Press, 1991.

[3] T. Nixon, Prioritisasi Tugas Pada Proses Perancangan Prosuk Dengan Menggunakan Metode Quality Function Deployment dan Design Structure Matrix, Medan: University of North Sumatera, 2014.

[4] M. G. d. Silva dkk, "MEMS Design for Manufacturability (DFM).," Sensors Expo \& conference 2002, 2002.

[5] S. Yusuf, "Metode Seleksi Material pada Pengilangan Minyak dan Gas Menggunakan Neraca Massan dan Energi dan Diagram Alir Proses," Journal of Aceh Physics Society, vol. Vol. 6 No. 1, 2017.

[6] R. M. Barnes, Motion and Time Study Design and Measurement of Work, Singapore: Wiley and Sons, 1980 . 